\title{
Pola Penggunaan Obat Herbal sebagai Terapi Komplementer pada Pasien Hiperkolesterol di Puskesmas Kota Pangkalpinang Tahun 2020
}

\author{
Patterns of Using Herbal Medicines as Complementary Therapy in \\ Hypercolesterol Patients at Puskesmas, Pangkalpinang City, 2020
}

\author{
Ana Husnayanti ${ }^{1}$, Zahriah $^{2}$ \\ 1. Politeknik Kesehatan Kementerian Kesehatan Pangkalpinang, Indonesia \\ 2. . Politeknik Kesehatan Kementerian Kesehatan Pangkalpinang, Indonesia \\ *Email Korespondensi: ricky.husna160819@gmail.com
}

\begin{abstract}
Abstrak
Latar belakang: Penggunaan obat tradisional sebagai bagian dari pengobatan Hiperkolesterol semakin meningkat. Salah satu faktor yang berkontribusi adalah harga yang murah disamping itu, efek samping yang ditimbulkan dianggap lebih sedikit. Tanaman obat yang digunakan untuk menurunkan kolesterol antara lain bawang putih, Binahong (Anredera cordifolia), Markisa (Passiflora edulis), Teh olong (Camelia sinensis), Daun sirsak (Annona muricata), Bidara (Ziziphus mauritiana).

Tujuan: Penelitian ini adalah mengetahui pola penggunaan obat bahan alam sebagai terapi komplementer pada pasien hiperkolesterol.

Metode: Penelitian ini bersifat diskriptif untuk mengetahui pola penggunaan obat bahan alam sebagai terapi komplementer pada pasien hiperkolesterol. Penelitian ini dilakukan di sembilan Puskesmas di Kota Pangkalpinang sepanjang bulan Maret 2020. Sampel yang digunakan adalah penderita Hiperkolesterol dan memenuhi kriteria sampel yang ditetapkan oleh peneliti. Dengan menggunakan rumus besar sampel untuk data nominal. Pengambilan sampel dilakukan tanpa acak (nonprabability sampling) dengan teknik pengambilan purposive sampling. Instrumen penelitian yang dipakai adalah lembar kuisioner. Kuisioner yang digunakan adalah kuisioner terbuka dan kuisioner tertutup.

Hasil: Penelitian menunjukkan Herbal yang paling banyak digunakan adalah daun salam (Syzygium polyantum Wight/Walp) baik kombinasi maupun tunggal dan bagian tumbuhan yang digunakan adalah daun. Cara penggunan herbal yang diracik sendiri oleh pasien hiperkolesterolemia sebagian besar dengan cara direbus (70\%). Frekuensi penggunaan herbal pada pasien hiperkolesterolemia sebagian besar adalah satu kali sehari (64\%). Takaran/dosis herbal yang digunakan oleh pasien hiperkolesterolemia yang meracik herbal sendiri masih dalam jumlah perkiraan (lembar, sejempol, segenggam, sejumput, batang, buah, siung, secukupnya).
\end{abstract}

Kesimpulan: Terdapat hubungan antara jenis kelamin dengan pemilihan penggunaan herbal. Namun demikian, tidak terdapat hubungan antara usia pasien dengan pemilihan penggunaan herbal.

Kata kunci : Kolestrol; Obat Herbal; Pengobatan Komplementer

\begin{abstract}
Background: The use of traditional medicine as part of the treatment of hypercholesterolemia is increasing. One of the contributing factors is the low price. Besides, the side effects are considered less. Medicinal plants used to lower cholesterol include garlic, Binahong (Anredera cordifolia), passion fruit (Passiflora edulis), olong tea (Camelia sinensis), soursop leaves (Annona muricata), Bidara (Ziziphus mauritiana).

Objective: This research aimed at natural medicine as a complementary therapy in hypercholesterolemic patients

Method: This study is descriptive in nature to determine the pattern of using natural medicine as a complementary therapy in hypercholesterolemic patients. This research was conducted at nine health centers (Puskesmas) in Pangkalpinang City throughout March 2020. The sample used was hypercholesterol sufferers and met the sample criteria set by the researcher. By using the sample size
\end{abstract}


formula for nominal data. Sampling was done without random (nonprabability sampling) with purposive sampling technique. The research instrument used was a questionnaire sheet. The questionnaire used is an open questionnaire and a closed questionnaire

Result: The results showed that the most widely used herbs were the bay plant (Syzygium polyantum Wight/Walp) both combination and single and the plant part used was the leaves. How to use herbs that are formulated by hypercholesterolemic patients mostly by boiling (70\%). The frequency of using herbs in hypercholesterolemic patients is mostly once a day (64\%). The dosage / dosage of herbs used by hypercholesterolemic patients who mix their own herbs is still in approximate numbers (sheet, thumb, handful, pinch, stem, fruit, cloves, to taste).

Conclusion: There is a relationship between gender and the choice of herbal use. However, there is no relationship between patient age and the choice of herbal use.

Keywords: Cholesterol; Complementary Medicine; Herbal Medicine

\section{PENDAHULUAN}

Hiperlipidemia (hiperkolesterol) adalah disregulasi metabolik tubuh dengan diabetes melitus, peningkatan kadar trigliserida, kolestrol dan LDL dalam serum dan menjadi faktor utama penyakit kardiovaskular salah satunya hipertensi (1). Penyebab hiperlipidemia adalah umur, jenis kelamin, latar belakang Pendidikan, indeks masa tubuh, aktivitas olahraga, penyakit keturunan, dan pola makan. Mengkonsumsi makanan tinggi kolesterol dan lemak jenuh menyebabkan peningkatan kolesterol intrasel dan akan disimpan sebagai ester kolesterol yang menyebabkan penurunan transkripsi gen reseptor High Density-Lipoprotein (HDL) dan menurunkan sintesis LDL (2).

Prevelensi hiperkolesterol di Indonesia berdasarkan hasil Profil Penyakit Tidak Menular (PTM) yang diterbitkan oleh kemenkes tahun 2016, persentase kolesterol tinggi yang tercatat di Pos Pembinaan Terpadu (Posbindu). Dimana diderita oleh laki - laki sebesar $48 \%$ dan perempuan $54.3 \%$. Menurut data provinsi, persentase pengunjung dengan kolesterol tinggi di posbindu dan FKTP di Indonesia paling tinggi di Provinsi Papua Barat yaitu 70\% disusul oleh Provinsi Kepulauan Bangka Belitung sebesar 57,7\% (4).

Data Riset Kesehatan Dasar (Riskesdas) tahun 2010 menunjukkan 60\% penduduk Indonesia diatas usia 15 tahun menyatakan pernah minum jamu, dan $90 \%$ diantaranya menyatakan adanya manfaat minum jamu. Data Riskesdas tahun 2013 menyatakan bahwa 30,4\% rumah tangga di Indonesia memanfaatkan pelayanan kesehatan tradisional, dimana diantaranya $49 \%$ rumah tangga memanfaatkan ramuan obat tradisional. Pengobatan hiperkolesterol tidak jarang menggunakan lebih dari satu obat. Pengobatan kombinasi merupakan salah satu strategi penatalaksanaan lipid yang optimum, yaitu dengan menggunakan dua macam obat yang mempunyai mekanisme kerja yang berbeda (5).

Deklarasi Alma-Ata tahun 1978 merupakan salah satu wujud pengakuan World Health Organization (WHO) terhadap penggunaan obat tradisional sebagai komponen penting dalam pelayanan kesehatan dasar (6). Keseriusan Pemerintah dalam mendukung pemanfaatan obat tradisional terlihat dari beberapa peraturan yang telah dikeluarkan, salah satunya saintasi Jamu (5). Penggunaan obat tradisional sebagai bagian dari pengobatan Hiperkolesterol semakin meningkat. Salah satu faktor yang berkontribusi adalah harga yang murah disamping itu, efek samping yang ditimbulkan dianggap lebih sedikit (6). Tanaman obat yang digunakan untuk menurunkan kolesterol antara lain bawang putih, Binahong (Anredera cordifolia) (7), Markisa (Passiflora edulis) (8), Teh Hijau (Camelia sinensis) (10), Daun sirsak (Annona muricata) (10) dan Bidara (Ziziphus mauritiana).

Penelitian ini dilakukan untuk mengetahui pola penggunaan obat herbal sebagai terapi komplementer pada pasien hiperkolesterol, meliputi:1). nama dan bagian dalam pengobatan 
Hiperkolesterol; 2). cara penggunaan herbal yang digunakan dalam pengobatan Hiperkolesterol; 3). frekuensi penggunaan herbal yang digunakan dalam pengobatan Hiperkolesterol; 4). dosis penggunaan herbal yang digunakan dalam pengobatan hiperkolestrol; dan 5). hubungan usia dan jenis kelamin terhadap pilihan penggunaan herbal.

\section{METODE}

Penelitian ini bersifat deskriptif untuk mengetahui pola penggunaan obat herbal sebagai terapi komplementer pada pasien hiperkolesterol. Penelitian ini dilakukan di 9 Puskesmas di Kota Pangkalpinang, yaitu Puskesmas Air Itam, Puskesmas Selindung, Puskesmas Taman Sari, Puskesmas Kacang Pedang, Puskesmas Girimaya, Puskesmas Melintang, Puskemas Gerunggang, Puskesmas Pangkal Balam, dan Puskesmas Pasir Putih. Pengambilan data pasien dilakukan dari tanggal 1 Oktober- 30 Oktober 2020.

Populasi penelitian ini adalah pasien yang teridentifikasi mengalami hipekolesterol berdasarkan catatan hasil pemeriksaan kadar kolesterol total (>240 mg/dL) di setiap Puskesmas pada periode Januari-Spetember 2020. Jumlah pasien yang teridentifikasi mengalami hiperkolestrol dalam periode tersebut adalah 635 pasien.

Sampel dalam penelitian ini adalah bagian dari populasi pasien hiperkolesterol yang ada di sembilan Puskesmas pada periode Januari-September 2020. Besar sampel ditentukan dengan menggunakan rumus besar sampel untuk data nominal. Pengambilan sampel dilakukan tanpa acak (nonprabability sampling) dengan teknik pengambilan accidental sampling, yaitu pengambilan sampel yang tidak ditentukan secara khusus terlebih dulu, namun pengumpulan sampel langsung dari unit sampling yang ditemui. Setelah jumlah sampel terpenuhi pengumpulan data dihentikan. Penentuan jumlah sampel untuk setiap puskesmas dilakukan secara stratified sampling.

Setiap responden yang terlibat dalam penelitian ini diberikan inform consent dan diminta secara sukarela sehingga semua yang terlibat sebagai responden secara sadar dan sukarela terlibat. Penelitian ini sudah lulus kaji etik dari Komisi Etik Poltekkes Kemenkes Pangkalpinang dengan nomor 17/EC/KEPK-PKP/IV/2020.

Dari jumlah populasi tersebut, peneliti menetapkan jumlah sampel yang diambil dalam penelitian ini adalah sebesar 100 pasien. Berdasarkan catatan hasil pemeriksaan laboratorium menunjukkan bahwa rata-rata kadar kolesterol total pasien sebesar $272 \pm 31 \mathrm{mg} / \mathrm{dL}$. Sebagian besar pasien yang mengalami hiperkolesterol adalah pasien dengan jenis kelamin perempuan $(87 \%)$. Kelompok usia yang paling banyak mengalami hiperkolesterol adalah pasien dengan usia $\geq 60$ tahun (49\%). Selain itu, latar belakang pendidikan pasien menunjukkan bahwa pasien terbanyak yang menjadi sampel dalam penelitian ini adalah lulusan Sekolah Menengah Atas (37\%) sedangkan latar belakang pekerjaan pasien yang tertinggi dalam penelitian ini adalah Ibu Rumah Tangga (73\%).

Data dalam penelitian merupakan data kategorik. Pengumpulan data dilakukan dengan menggunakan instrumen kuesioner. Kuesioner penelitian ini terdiri dari pertanyaan terbuka dan tertutup. Analisis data dalam penelitian dilakukan secara kuantitatif. Data akan ditampilkan dalam bentuk distribusi frekuensi dan untuk penilaian hubungan antara variabel usia dan jenis kelamin dengan penggunaan herbal dilakukan uji Chi-Square.

\section{HASIL}

Pasien hiperkolesterolemia dalam penelitian ini sebagian besar telah menderita hiperkolesterol lebih dari 1 tahun (58\%). Mayoritas pasien menggunakan obat konvensional dalam terapi hiperkolesterolnya baik secara tunggal maupun dikombinasikan dengan herbal (89\%), namun demikian sejumlah kecil pasien menunjukkan bahwa terapi hiperkolesterol yang mereka pakai hanya mengunakan herbal $(11 \%)$. Obat konvensional yang digunakan oleh pasien adalah 
golongan statin dengan persentase terbesar yaitu simvastatin (94\%). Frekuensi penggunaan obat antikolesterol tertinggi adalah penggunaan 1 kali sehari (96\%). Sebagian besar pasien menggunakan obat antikolesterol konvensional pada malam hari (99\%). Data selengkapanya dapat dilihat pada Tabel di bawah ini:

Tabel 1. Lama Menderita Hiperkolesterol, Penggunaan Obat Konvensional dan Frekuensi Penggunaannya pada Pasien Hiperkolesterolemia

\begin{tabular}{|c|c|c|}
\hline Indikator & Jumlah (n) & Persentase \\
\hline \multicolumn{3}{|c|}{ Lama Menderita Hiperkolesterol } \\
\hline$<6$ Bulan & 27 & $27 \%$ \\
\hline 6 Bulan - 1 Tahun & 15 & $15 \%$ \\
\hline$>1$ Tahun & 58 & $58 \%$ \\
\hline Jumlah & 100 & $100 \%$ \\
\hline \multicolumn{3}{|c|}{ Penggunaan Obat Konvensional } \\
\hline Menggunakan & 89 & $89 \%$ \\
\hline Tidak Menggunakan & 11 & $11 \%$ \\
\hline Jumlah & 100 & $100 \%$ \\
\hline \multicolumn{3}{|c|}{ Nama Obat Konvensional yang digunakan } \\
\hline Simvastatin & 84 & $94 \%$ \\
\hline Atorvastatin & 5 & $6 \%$ \\
\hline Jumlah & 89 & $100 \%$ \\
\hline \multicolumn{3}{|c|}{ Frekuensi Penggunaan Obat } \\
\hline 1 Kali & 85 & $96 \%$ \\
\hline 2 Kali & 3 & $3 \%$ \\
\hline 3 Kali & 1 & $1 \%$ \\
\hline Jumlah & 89 & $100 \%$ \\
\hline
\end{tabular}

Jumlah pasien hiperkolesterolemia yang menggunakan herbal menunjukkan perbandingan yang sama dengan yang tidak menggunakan herbal (50\%). Pasien hiperkolesterolemia yang telah menggunakan obat konvensional sebelumya, menunjukkan bahwa sebagian besar memilih menghentikan obat konvensional mereka dan beralih hanya menggunakan herbal (56\%), namun sebagian yang lain masih tetap menggunakan obat konvensional bersama herbal dalam terapi hiperkolesterol mereka (44\%). Pasien yang menggunakan obat konvensional bersama herbal menunjukkan bahwa mereka menggunakan obat konvensional terlebih dahulu sebelum menggunakan herbal (77\%), dan jarak antara waktu penggunaan obat konvensional dengan herbal adalah lebih dari 6 jam (41\%). Frekuensi penggunaan herbal yang tertinggi adalah satu kali sehari (64\%).

Herbal yang digunakan oleh pasien hiperkolesterol sebagian besar merupakan herbal tunggal (54\%), penggunaan kombinasi herbal yang diracik sendiri sebanyak $38 \%$ dan sisanya adalah menggunakan produk herbal yang ada di pasaran $(8 \%)$. Tumbuhan obat yang paling banyak digunakan oleh pasien sebagai antikolesterol baik dalam sediaan tunggal maupun kombinasi adalah daun salam (Syzygium polyantum (Wight) Walp).

Cara penggunaan herbal sebagian besar dilakukan dengan perebusan $(70 \%)$ dan sebagian besar dari bagian herbal yang digunakan adalah daun. Data terkait penggunaan herbal dapat dilihat secara lengkap pada tabel-tabel di bawah ini: 
Tabel 2. Penggunaan Herbal pada Pasien Hiperkolesterolemia

\begin{tabular}{|c|c|c|}
\hline Komponen Informasi & Jumlah (n) & Persentase \\
\hline \multicolumn{3}{|l|}{ Penggunaan Herbal } \\
\hline Menggunakan & 50 & $50 \%$ \\
\hline Tidak Menggunakan & 50 & $50 \%$ \\
\hline Jumlah & 100 & $100 \%$ \\
\hline \multicolumn{3}{|l|}{ Penghentian Obat Konvensional } \\
\hline Dihentikan & 28 & $56 \%$ \\
\hline Tidak Dihentikan & 22 & $44 \%$ \\
\hline Jumlah & 50 & $100 \%$ \\
\hline \multicolumn{3}{|l|}{ Urutan Penggunaan Obat } \\
\hline Obat Konvensional Dilanjutkan Herbal & 17 & $77 \%$ \\
\hline Herbal dilanjutkan Obat Konvensional & 5 & $23 \%$ \\
\hline Jumlah & 22 & $100 \%$ \\
\hline \multicolumn{3}{|c|}{ Jarak waktu penggunaan obat konvensional dengan Herbal } \\
\hline$<1 \mathrm{Jam}$ & 0 & $0 \%$ \\
\hline 1-3 Jam & 6 & $27 \%$ \\
\hline 3-6 Jam & 7 & $32 \%$ \\
\hline$>6 \mathrm{Jam}$ & 9 & $41 \%$ \\
\hline Jumlah & 22 & $100 \%$ \\
\hline \multicolumn{3}{|l|}{ Frekuensi Penggunaan Herbal } \\
\hline 1 kali & 32 & $64 \%$ \\
\hline 2 kali & 11 & $22 \%$ \\
\hline 3 kali & 6 & $12 \%$ \\
\hline 5 kali & 1 & $2 \%$ \\
\hline Jumlah & 50 & $100 \%$ \\
\hline \multicolumn{3}{|l|}{ Cara Penggunaan Herbal } \\
\hline Direbus & 35 & $70 \%$ \\
\hline Langsung diminum & 7 & $14 \%$ \\
\hline Diseduh & 5 & $10 \%$ \\
\hline Dijus & 2 & $4 \%$ \\
\hline Direndam air mineral & 1 & $2 \%$ \\
\hline Jumlah & 50 & $100 \%$ \\
\hline \multicolumn{3}{|l|}{ Bagian Herbal yang Digunakan } \\
\hline Daun (Tunggal) & 30 & $60 \%$ \\
\hline Rimpang (Tunggal) & 4 & $8 \%$ \\
\hline Buah (Tunggal) & 3 & $6 \%$ \\
\hline Kombinasi Batang dan Rimpang & 3 & $6 \%$ \\
\hline Kombinasi Daun dan rimpang & 2 & $4 \%$ \\
\hline Kombinasi Daun dan Umbi & 1 & $2 \%$ \\
\hline Kombinasi Rimpang dan buah & 3 & $6 \%$ \\
\hline Sirup (Produk Jadi) & 1 & $2 \%$ \\
\hline Biji & 1 & $2 \%$ \\
\hline Kombinasi Buah dan daun & 1 & $2 \%$ \\
\hline Kombinasi Buah, rimpang dan batang & 1 & $2 \%$ \\
\hline Jumlah & 50 & $100 \%$ \\
\hline
\end{tabular}




\section{Tabel 3. Nama Herbal yang Digunakan}

\begin{tabular}{|c|c|c|c|}
\hline Nama Herbal & Nama latin & Jumlah (n) & Persentase \\
\hline \multicolumn{4}{|c|}{ Herbal Tunggal } \\
\hline Daun Salam & Syzygium polyantum (Wight) Walp & 6 & $12 \%$ \\
\hline Daun Afrika & Vernoiae amygdalinae & 1 & $2 \%$ \\
\hline Daun Insulin & Smallanthus sonchifolius & 1 & $2 \%$ \\
\hline Daun Sirih & Piperis betle $L$ & 2 & $4 \%$ \\
\hline Tidak Diketahui & & 1 & $2 \%$ \\
\hline Daun Sirsak & Annonae Muricatae & 2 & $4 \%$ \\
\hline Jahe & Zingiberis officinale & 2 & $4 \%$ \\
\hline Daun Sambung Nyawa & Gynurae procumbensis & 3 & $6 \%$ \\
\hline Daun Wungu & Graptophylli picti & 1 & $2 \%$ \\
\hline Daun Ceri & Muntingia calabura & 1 & $2 \%$ \\
\hline Daun Sambiloto & Andrographidis paniculatae & 3 & $6 \%$ \\
\hline Daun Binahong & Anrederae cordifoliae & 2 & $4 \%$ \\
\hline Buah Ketumbar & Coriandri sativi & 1 & $2 \%$ \\
\hline Buah Markisa & Passiflora edulis & 1 & $2 \%$ \\
\hline Jeruk Nipis & Citrus aurantifolia & 1 & $2 \%$ \\
\hline Total & & 27 & $54 \%$ \\
\hline \multicolumn{4}{|c|}{ Herbal Kombinasi Racikan Sendiri } \\
\hline $\begin{array}{l}\text { Daun Jati Belanda Dan Daun } \\
\text { Sirsak }\end{array}$ & Guazuma ulmifolia Lam dan Annonae Muricatae & 1 & $2 \%$ \\
\hline Serai (Sereh) Dan Jahe & Andropogon nardus Linn dan Zingiberis officinale & 3 & $6 \%$ \\
\hline $\begin{array}{l}\text { Daun Sambung Nyawa Dan Tapak } \\
\text { Dara }\end{array}$ & Gynurae procumbensis, catharanthus roseus & 1 & $2 \%$ \\
\hline Daun Sirih Merah Dan Daun Salam & $\begin{array}{l}\text { Piper crocatum Ruiz \& Pav dan Syzygium polyantum } \\
\text { (Wight) Walp }\end{array}$ & 1 & $2 \%$ \\
\hline Daun Salam, Serai, Kunyit, Jahe & $\begin{array}{l}\text { Syzygium polyantum (Wight) Walp Andrpogon nardus } \\
\text { Linn,Curcuma Longa, Zingiberis officinale }\end{array}$ & 1 & $2 \%$ \\
\hline $\begin{array}{l}\text { Daun Kumis Kucing Dan Daun } \\
\text { Salam }\end{array}$ & $\begin{array}{l}\text { Orthosiphon stamineus Benth dan Syzygium polyantum } \\
\text { (Wight) Walp }\end{array}$ & 1 & $2 \%$ \\
\hline Daun Salam Dan Jahe & $\begin{array}{l}\text { Syzygium polyantum (Wight) Walp dan Zingiberis } \\
\text { officinale }\end{array}$ & 1 & $2 \%$ \\
\hline Daun Salam Dan Daun Ceri & Syzygium polyantum (Wight) Walp, Muntingia calabura & 1 & $2 \%$ \\
\hline Rimpang Kunyit dan Buah Asam & Curcuma Longa, Tamarinus indica & 1 & $2 \%$ \\
\hline Daun Ceri Dan Daun Sirsak & Muntingia calabura, Annonae Muricatae & 1 & $2 \%$ \\
\hline $\begin{array}{l}\text { Jahe,Serai,Temulawak,Kayu Manis } \\
\text { Dan Jeruk Nipis }\end{array}$ & $\begin{array}{l}\text { Zingiberis officinale, Andropogon nardus Linn, Curcuma } \\
\text { xanthorrhiza Roxb, Cinnamomum burmanii (Nees } \\
\text { \&T.ees), Citrus aurantifolia }\end{array}$ & 1 & $2 \%$ \\
\hline Buah Rosela Dan Mahkota Dewa & Hibiscus sabdariffa L, Phaleria macrocarpa (Scheff) & 1 & $2 \%$ \\
\hline Kunyit, Temulawak & Curcuma Longa, Curcuma xanthorrhiza Roxb & 1 & $2 \%$ \\
\hline Daun Alpukat,Kumis Kucing & Persae americana Mill, Orthosiphon stamineus Benth & 1 & $2 \%$ \\
\hline Jahe Dan Sirsak & Zingiberis officinale, Annonae Muricatae & 1 & $2 \%$ \\
\hline $\begin{array}{l}\text { Bawang Putih Tunggal, Daun } \\
\text { Salam }\end{array}$ & Allium sativum L, Syzygium polyantum (Wight) Walp & 1 & $2 \%$ \\
\hline $\begin{array}{l}\text { Jeruk Nipis, Madu,Garam } \\
\text { Himalaya }\end{array}$ & Citrus aurantifolia & 1 & $2 \%$ \\
\hline Total & & 19 & $38 \%$ \\
\hline \multicolumn{4}{|l|}{ Herbal Produk Jadi } \\
\hline Ekstrak Gamat (Gold-g) & & 1 & $2 \%$ \\
\hline Serbuk Mint Klorofil (CMP) & & 1 & $2 \%$ \\
\hline $\begin{array}{l}\text { Esktrak Madu Tawon Liar }+ \\
\text { Tumbuhan Obat+Zat Tambahan } \\
\text { (Tawon liar) }\end{array}$ & & 1 & $2 \%$ \\
\hline $\begin{array}{l}\text { Sirup kombinasi Bawang putih, } \\
\text { cuka apel, madu,jahe dan lemon( } \\
\text { Sano) }\end{array}$ & & 1 & $2 \%$ \\
\hline Total & & 4 & $\mathbf{8 \%}$ \\
\hline Total Seluruh Herbal & & $\mathbf{5 0}$ & $100 \%$ \\
\hline
\end{tabular}


Penggunaan herbal pasien hiperkolesterolemia terdiri dari takaran, jumlah dan persentase di bawah ini

Tabel 4. Takaran Jumlah Herbal Pasien Hiperkolesterolemia

\begin{tabular}{ccc}
\hline Takaran & Jumlah (n) & Persentase \\
\hline Direbus dgn 3 gelas air & 2 & $4 \%$ \\
\hline 7 Lembar & 9 & $18 \%$ \\
\hline 5 Lembar & 4 & $8 \%$ \\
\hline 3 btg serai,1 jempol jahe & 2 & $4 \%$ \\
\hline 3 Lembar & 4 & $8 \%$ \\
\hline Segenggam & 5 & $10 \%$ \\
\hline Sejempol/2 jempol & 4 & $8 \%$ \\
\hline 9 Lembar & 3 & $6 \%$ \\
\hline 1 sdm & 2 & $4 \%$ \\
\hline 10 lembar & 2 & $4 \%$ \\
\hline 1 kapsul/bungkus & 2 & $4 \%$ \\
\hline 1 buah & 2 & $4 \%$ \\
\hline 3,5,7 lembar & 2 & $2 \%$ \\
\hline 5 lembar, sejempol & 1 & $2 \%$ \\
\hline 5 lembar & 1 & $2 \%$ \\
\hline 20 lembar & 1 & $2 \%$ \\
\hline 3 siung,11 lembar & 1 & $2 \%$ \\
\hline buah,2 sdm,sejumput & 1 & $4 \%$ \\
\hline Secukupnya & 2 & $100 \%$ \\
\hline Total & 50 &
\end{tabular}

Beragam alasan dikemukakan oleh pasien terkait pilihan untuk menggunakan herbal dalam terapi hiperkolesterol. Alasan yang paling dominan adalah pasien merasa herbal lebih berkhasiat dibandingkan dengan obat konvensional (48\%). Data selengkapnya dapat dilihat di Tabel 5.

Tabel 5. Alasan Penggunaan Herbal pada Pasien Hiperkolesterolemia

\begin{tabular}{lcc}
\hline \multicolumn{1}{c}{ Alasan Penggunaan } & Jumlah (n) & Persentase \\
\hline Harga (Herbal Murah) & 2 & $4 \%$ \\
\hline Kemudahan didapatkan & 14 & $28 \%$ \\
\hline Khasiat (herbal Lebih berkhasiat) & 24 & $48 \%$ \\
\hline Keamanan (Herbal Aman) & 7 & $14 \%$ \\
\hline Informasi teman/tetangga & 3 & $6 \%$ \\
\hline Jumlah & 50 & $100 \%$ \\
\hline
\end{tabular}

Pasein hiperkolestrolemia di wilayah kerja Sembilan puskesmas yang ada di pangkalpinang menunjukkan bahwa sebagian besar merupakan pasien perempuan (87\%), hasil ini sesuai dengan penelitian tentang beberapa fasilitas pelayanan kesehatan di Indonesia yang tergabung dalam jejaring pengobatan tradisional (11) yang menunjukkan bahwa mayoritas pasien hiperkolesterolemia merupakan perempuan. Sedangkan penelitian lain di Rumah Riset Jamu 'Hortus Medicus' (12) menunjukkan bahwa mayoritas pasien hiperkolesterolemia merupakan laki-laki. Jika ditinjau dari aspek usia,mayoritas pasien hiperkolesterolemia pada penelitian ini merupakan pasien yang berusia lebih dari 60 tahun (49\%). Hasil ini serupa dengan 
penelitian yang sama (12) di Rumah Riset Jamu 'Hortus Medicus' menunjukkan bahwa mayoritas pasien hiperkolesterolemia berusia > 60 Tahun (42\%). Hasil ini juga diperkuat dengan pernyataan dari Reiner et al. (2017), bahwa laki-laki usia $\geq 40$ tahun atau wanita dengan usia $\geq 50$ tahun memiliki risiko yang tinggi terhadap timbulnya hiperkolesterolemia.

Usia dan Jenis Kelamin merupakan 2 (dua) dari beberapa faktor risiko hiperkolesterolemia. Pada umumnya dengan bertambahnya usia (semakin menua), aktifitas fisik menurun, massa tubuh tanpa lemak menurun, sedangkan jaringan lemak bertambah (13). Patofisiologi perubahan komposisi tubuh menyebabkan penurunan massa tulang, sedangkan hormon yang mengatur metabolisme menurun sesuai dengan umur (seperti insulin, hormon pertumbuhan dan androgen) sedangkan yang lain meningkat (seperti prolaktin). Penurunan beberapa jenis hormon ini menyebabkan penurunan massa tanpa lemak, sedangkan peningkatan aktifitas hormon lainnya meningkatkan massa lemak.

Hormon seks pada wanita, yaitu estrogen diketahui dapat menurunkan kolesterol darah dan hormon seks pria yaitu andogen dapat meningkatkan kadar kolesterol darah (14). Maka dari itu, kurangnya hormon estrogen akibat menopause pada perempuan menyebabkan meningkatnya lemak perut, meningkatnya kolesterol total dan lebih berisiko mengalami penyakit jantung (15). Berdasarkan jenis kelamin, laki-laki usia dibawah 50 tahun memiliki resiko 2-3 kali lebih besar mengalami aterosklerosis oleh kolesterol dibandingkan dengan wanita. Sementara wanita usia diatas 50 tahun atau sudah menopause, memiliki risiko yang sama dengan laki-laki. Masa menopause wanita yang dilindungi oleh hormon esterogen, sehingga dipercaya mencegah terbentuknya aterosklerosis. Esterogen dalam kaitan dengan kolesterol bekerja dengan cara meningkatkan HDL dan menurunkan LDL pada darah. Setelah menopause, kadar esterogen pada wanita akan menurun, risiko hiperkolesterol dan aterosklerosis akan menjadi setara dengan laki- laki (15).

\section{PEMBAHASAN}

Berdasarkan jumlah pasien hiperkolesterolemia dalam penggunaan herbal dan obat konvensional menunjukkan kecenderungan penggunaan herbal yang sebanding dengan penggunaan obat konvensional. Jika dilihat keterkaitannya, maka dapat kita identifikasi dari hasil penelitian pada Tabel 4.7 bahwa jenis kelamin memberikan pengaruh pada pemilihan penggunaan herbal sedangkan usia tidak menunjukkan pengaruh terhadap pemilihan penggunaan herbal.

Tabel 6. Hubungan Jenis Kelamin dan Usia Terhadap Penggunaan Herbal

\begin{tabular}{lccccc}
\hline \multirow{2}{*}{ Karakteristik Pasien } & \multicolumn{3}{c}{ Penggunaan Herbal } & \multirow{2}{*}{ P value } \\
\cline { 2 - 6 } & Ya & $\%$ & Tidak & $\%$ & \\
\hline Usia & 2 & $40 \%$ & 3 & $60 \%$ \\
\hline $26-34$ & 7 & $35 \%$ & 13 & $65 \%$ \\
\hline $34-42$ & 11 & $42 \%$ & 15 & $58 \%$ \\
\hline $43-51$ & 30 & $61 \%$ & 19 & $39 \%$ \\
\hline$>60$ & 50 & & 50 & \\
\hline Total & & & & \\
\hline Jenis Kelamin & 39 & $45 \%$ & 48 & $55 \%$ \\
\hline Perempuan & 11 & $85 \$$ & 2 & $15 \%$ & \\
\hline Laki-laki & 50 & & 50 & & \\
\hline Total & & & & \\
\hline
\end{tabular}

Hasil penelitian ini diperkuat dengan penelitian yang dilakukan oleh (16) yang juga menyatakan bahwa tidak ada hubungan antara usia pasien dengan penggunaan herbal. Namun demikian, penelitian yang dilakukan oleh (12) di Rumah Riset Jamu 'Hortus Medicus' menunjukkan bahwa terdapat hubungan antara usia pasien dengan pemilihan penggunaan herbal. Selain itu, hubungan jenis kelamin pasien dengan pemilihan penggunaan herbal dalam 
penelitian ini menunjukkan ada hubungan yang signifikan antara jenis kelamin pasien dengan pemilihan penggunaan herbal. Dari hasil ini, dapat dilihat bahwa pasien yang berjenis kelamin laki-laki lebih cenderung untuk menggunakan herbal. Hasil ini sesuai dengan penelitian (12) di Rumah Riset Jamu 'Hortus Medicus' yang menunjukkan bahwa pasien laki-laki teridentifikasi lebih dominan dalam penggunaan herbal.

Penggunaan herbal yang teridentifikasi dalam penelitian ini sebagian besar adalah herbal tunggal (54\%), sedangkan sisanya adalah herbal kombinasi baik yang diracik sendiri maupun dalam produk jadi yang beredar di pasaran. Penggunaan herbal dalam kombinasi lebih dari dua tanaman seringkali digunakan untuk meningkatkan efek terapi dengan harapan adanya sinergisitas antar tanaman. Namun demikian, penggunaan tanaman obat dalam kombinasi lebih dari dua tanaman juga harus diwaspadai, terlebih penggunaan kombinasi tersebut bukan atas rekomendasi praktisi herbal medis. Penggunaan kombinasi tanaman obat yang serampangan dapat menimbulkan gangguan kesehatan lain bahkan dapat memperburuk kondisi pasien. Maka diperlukan riset selanjutnya agar mendapatkan data keamanan penggunaan kombinasi tumbuhan obat pada pasien hipekolesterolemia.

Pada penelitian ini, teridentifikasi ada empat produk herbal yang digunakan oleh pasien hiperkolesterolemia. Diantara keempat produk tersebut, dua diantaranya tidak memiliki legalitas dari BPOM (Badan Pengawas Obat dan Makanan). Hal ini diketahui dari tidak ditemukannya data terkait nama dua produk tersebut di mesin pencarian obat terregister BPOM (19). Adapun dua dari nama produk tersebut adalah Sirup Sano dan Tawon Liar. Tawon Liar merupakan Produk herbal yang telah dimasukkan dalam daftar obat herbal yang dilarang oleh BPOM karena terbukti mengandung BKO (Bahan Kimia Obat) yaitu paracetamol.

Sedangkan Sirup Sano adalah produk yang dipasarkan dengan kalimat sugesti yang sangat hiperbolis dalam kemasannya yaitu 'Sirup Ajaib Keluarga'. Dalam aspek justifikasi khasiat dari produk herbal yang belum terbukti secara ilmiah baik melalui uji pre klinik maupun uji klinik, maka justifikasi khasiat dengan kata "mengobati" dan melabelkan kata 'Ajaib' tidak dibenarkan. Komposisi bahan yang ada di dalam produk ini mengandung lebih dari dua tanaman. Tidak adanya legalitas produk ini dari BPOM, maka tidak ada jaminan bahwa komponen tanaman yang tertuliskan di label adalah bahan yang sama dengan yang sebenarnya ada di dalam produk tersebut. Selain itu, tidak ada jaminan terkait keamanan produk tersebut mulai dari kondisi tanaman yang dipilih hingga proses produksi herbal tersebut.

Tumbuhan obat yang paling sering dipakai oleh pasien hiperkolesterolemia adalah daun salam (Syzygium polyantum (Wight) Walp). Mekanisme kerja daun salam sebagai antikolesterol adalah dengan menghambat enzim HMG-CoA reduktase, sehingga sintesis kolesterol menjadi terhambat (17). Mekanisme kerja tumbuhan ini sama dengan mekanisme kerja obat antikolesterol golongan statin. Jika ditinjau dari waktu penggunaan obat yang dikemukakan oleh pasien menunjukkan bahwa sebagian besar pasien menggunakan obat konvensionalnya di malam hari dan menggunakan herbal di waktu setelahnya. Dengan perbedaan waktu tersebut dan adanya kesamaan mekanisme kerja, maka penghambatan sintesis kolesterol dapat diperkirakan lebih besar.

Daun salam sebagai tumbuhan obat harus digunakan secara berhati-hati, terlebih untuk pasien-pasien yang juga mendapatkan obat lain seperti obat antidiabetes. Penggunaan daun salam bersama obat antidiabetes (Metformin) dapat menyebabkan penurunan gula darah secara signifikan/drastis (kondisi ini dikhawatirkan berakhir pada hipoglikemi (18).

Frekuensi penggunaan herbal pada pasien hiperkolesterolemia sebagian besar adalah satu kali sehari (64\%), Beberapa pasien menggunakan herbal 2-3 kali sehari. Salah satu tumbuhan obat yang frekuensi penggunaannya lebih dari satu kali adalah daun salam dimana pasien-pasien tersebut juga menggunakan obat simvastatin dalam terapi mereka. Oleh karena itu, penting untuk menginformasikan kepada pasien terkait keamanan dari penggunaan obat 
tersebut. Jika dilihat dari data penelitian ini, dapat kita lihat bahwa telah teridentifikasi pasien yang menggunakan herbal dengan frekuensi 5 (lima) kali sehari. Pasien tersebut merupakan pasien yang memang hanya menggunakan herbal tanpa obat konvensional. Tumbuhannya obat yang digunakannya adalah daun sambung nyawa yang diolah dengan cara perebusan. Pasien tersebut merupakan pasien yang berusia lebih dari 40 tahun. Maka, penting untuk menginformasikan kepada pasien, khususnya pada pasien geriatri bahwa penggunaan herbal yang berlebihan dapat memperberat kerja organ tubuh yang sudah mengalami penurunan fungsi. Akibat dari kondisi ini dapat memperburuk kondisi pasien.

Jika ditinjau dari takaran penggunaan herbal, dapat dilihat bahwa pasien menggunakan herbal racikan sendiri dengan takaran yang masih dalam jumlah perkiraan. Selain itu takaran/jumlah bagian tumbuhan herbal yang digunakan belum seragam untuk tumbuhan yang sama. Sebagai contoh daun salam yang digunakan oleh beberapa pasien, menunjukkan variasi takaran yaitu 3 lembar, 5 lembar, 7 lembar, 11 lembar dan 15 lembar. Oleh karena itu, penting untuk dilakukan penelitian klinis terkait dengan dosis efektif daun salam dalam menurunkan kadar kolesterol total pasien.

\section{SIMPULAN}

Penelitian ini hanya membahas tentang penggunaan obat herbal bersamaan dengan obat kimia dan tidak membahas tentang interaksi farmakokinetik dan farmakodinamik dari obat kimia dengan obat herbal. Herbal yang paling banyak digunakan adalah tumbuhan salam (Syzygium polyantum (Wight Walp) baik secara kombinsi maupun tunggal dan bagian tumbuhan yang digunakan adalah daun. Cara penggunan herbal yang diracik sendiri oleh pasien hiperkolesterolemia sebagian besar dengan cara direbus (70\%). Frekuensi penggunaan herbal pada pasien hiperkolesterolemia sebagian besar adalah satu kali sehari (64\%). Takaran/dosis herbal yang digunakan oleh pasien hiperkolesterolemia yang meracik herbal sendiri masih dalam jumlah perkiraan (lembar, sejempol, segenggam, sejumput, batang, buah, siung, secukupnya). Terdapat hubungan antara jenis kelamin dengan pemilihan penggunaan herbal. Namun demikian, tidak terdapat hubungan antara usia pasien dengan pemilihan penggunaan herbal.

\section{SARAN}

Dibutuhkan riset dan penelitian yang lebih mendalam guna mengetahui efektifitas dan toksisitas tumbuhan obat (tunggal) yang belum ada data hasil uji prekliniknya sebagai antihiperkolesterol. Perlu penelitian lebih lanjut untuk mendapatkan data keamanan dan Efektivitas penggunaan kombinasi tumbuhan obat pada pasien hiperkolesterolemia. Perlu dilakukan penelitian klinis terkait dengan dosis efektif daun salam dan tumbuhan obat lainnya dalam menurunkan kadar kolesterol total pasien. Perlu dilakukan kegiatan pengabdian masyarakat dalam bentuk sosialisasi edukasi terkait keamanan penggunaan herbal.

\section{UCAPAN TERIMA KASIH}

Peneliti mengucapkan banyak terima kasih kepada Politeknik Kesehatan Kementerian Kesehatan Pangkalpinang, Kepala Puskesmas di Kota Pangkalpinang dan para responden serta semua pihak yang telah banyak membantu dalam penelitian ini.

\section{DAFTAR PUSTAKA}

1. Wahyu E. Saputri SAS. Aktivitas Antihiperlipidemia Pada Tanaman Herbal Dengan Metode Induksi Hewan Percobaaan. Farmaka. 2020;17:173-80. 
2. Supardi. MODEL PREDIKSI FAKTOR KEJADIAN HIPERLIPIDEMIA PESERTA ASKES DI KECAMATAN METRO TIMUR KOTA METRO PREDICTION MODEL FACTORS OF HYPERLIPIDEMIA EVENTS IN PARTICIPANTS ASKES IN EAST METRO DISTRICT Supardi Akademi Keperawatan Dharma Wacana Metro Supardi Kemajuan. Wacana Kesehat. 2018;3(1):282-95.

3. Kemenkes.RI. Profil Penyakit Tidak Menular Tahun 2016. Vol. 53, Direktorat Jenderal Penyakit Tidak Menular Kemenkes RI. 2017. 400 p.

4. RISKESDAS. Riset Kesehatan Dasar; Badan Penelitian dan Pengembangan Kesehatan Kementerian Kesehatan RI Tahun2010. Lap Nas 2010. 2013;1-446.

5. Soedirham O. Integrated Services Post (Posyandu) as Sociocultural Approach for Primary Health Care Issue. Kesmas Natl Public Heal J. 2012;7(5):195.

6. Delima D, Widowati L, Astuti Y, Siswoyo H, Gitawati R PA. Gambaran Praktik Penggunaan Jamu Oleh Dokter di Enam Provinsi di Indonesia. Bul Penelit Kesehat. 2012;40(3):109-22.

7. Hussaana A, Sarosa H, Indrayani UD, Chodidjah C, Widiyanto B PD. Formula Jamu Antihipertensi adn Captopril are equally effective in patients with hypertension. Universa Med. 2016;35(2):81-8.

8. Sutrisno E, Adnyana I.K, Sukandar E.Y F dan LT. KAJIAN AKTIVITAS PENYEMBUHAN LUKA DAN ANTIBAKTERI BINAHONG (Anredera cordifolia (Ten.) STEENIS, PEGAGAN (Centella asiatica (L.) Urban) SERTA KOMBINASINYA TERHADAP BAKTERI Staphylococcus aureus DAN Pseudomonas aeruginosa DARI PASIEN LUKA KAKI DIABETES. Bionatura-Jurnal Ilmu-ilmu Hayati dan Fis. 2014;16:78-82.

9. Yuldasheva LN, Carvalho EB, Catanho MT KO. Cholesterol-dependent hemolytic activity of Passiflora quadrangularis leaves. Braz J Med Biol Res. 2005;38:1061-70.

10. Mulyani NS, Arnisam W, Ermi P. PENGARUH PEMBERIAN TEH HIJAU (Camellia sinensis) TERHADAP TEKANAN DARAH PADA PENDERITA HIPERTENSI. AVERROUS J Kedokt dan Kesehat Malikussaleh. 2019;5(2):127.

11. Florence N.T., Benoit M.Z., Jonas K., Alexandra T., Desire D.D., Pierre K. TD. Antidiabetic and antioxidant effects of Annona muricata (Annonaceae), aqueous extract on streptozotocin-induced diabetic rats. J Ethnopharmacol. 2014;151:784-90.

12. Gusmi G. Gambaran Karakteristik Pemanfaatan Pelayanan Kesehatan Tradisional. J Ilm Kesehat. 2020;12(1):101-22.

13. Dewi, T. F., dan Nisa U. Faktor-Faktor yang Berhubungan dengan Pemanfaatan Obat Tradisional pada Pasien Hiperkolesterolemia di Rumah Riset Jamu "Hortus Medicus." J Farm Klin Indones. 2019;8:49-57.

14. Tridoyo, Sriyanto. Analisis Beban Kerja Dengan Metode Full Time Equivalent Untuk Mengoptimalkan Kinerja Karyawan Pada PT Astra International Tbk-Honda Sales Operation Region Semarang. J Undip. 2014;3(2):1-8.

15. Fatmah. Gizi Usia Lanjut. Jakarta: Penerbit Erlangga; 2010.

16. Ariani S. Stop Gagal Ginjal dan Gangguan-Gangguan Ginjal Lainnya. Yogyakarta: Istana Media; 2016.

17. Radji M, Aldrat H, Harahap Y IC. Penggunaan obat herbal pada pasien kanker serviks. J Ilmu Kefarmasian Indones. 2010;8:33-9.

18. Nuryanto I. OBAT TRADISIONAL DAN / ATAU JAMU HERBAL ( Perlindungan Hukum Mengenai Produksi Jamu / Obat Herbal Kemasan Yang Tidak Terdaftar Oleh BPOM ) Obat Tradisional dan / atau Jamu Herbal ( Perlindungan Hukum Mengenai Produksi Jamu / Obat Herbal Kemasan Yang Tidak. Progr Stud Strat 1 Ilmu Huk Univ Muhammadiyah Surakarta. 2020; 
19. Wijaya, S., Maureen, S., Yonas, K., Hartanti, L., Setiawan, H. K., Soegianto, L. \& SD. Studi pendahuluan: Korelasi Aktivitas Antikolesterol dengan Aktivitas Antioksidan Ekstrak Etanol Daun Salam ( Syzygium polyanthum ) Preliminary Study : Correlation of Anti-cholesterol Activity with Antioxidant Activity of Ethanol Extract of Bay leaf Leav. J Pharm Sciene Pract. 2018;5:100-11.

20. Suharmiati, \& Roosihermiatie B. yzygium Polyanthum Untuk Pengobatan Diabetes Mellitus. Prelim Study. 2012;110-9. 